\title{
Fractured Territories and Abstracted Terrains: Human Rights Governance Regimes Within and Beyond the State
}

\author{
Larry Catá Backer \\ Penn State Law, Icb11@psu.edu
}

Follow this and additional works at: https://www.repository.law.indiana.edu/ijgls

Part of the Comparative and Foreign Law Commons, Human Rights Law Commons, International Law Commons, Political Theory Commons, and the Transnational Law Commons

\section{Recommended Citation}

Backer, Larry Catá (2016) "Fractured Territories and Abstracted Terrains: Human Rights Governance Regimes Within and Beyond the State," Indiana Journal of Global Legal Studies: Vol. 23 : Iss. 1 , Article 4. Available at: https://www.repository.law.indiana.edu/ijgls/vol23/iss1/4

This Article is brought to you for free and open access by the Law School Journals at Digital Repository @ Maurer Law. It has been accepted for inclusion in Indiana Journal of Global Legal Studies by an authorized editor of Digital Repository @ Maurer Law. For more information, please contact rvaughan@indiana.edu.

\section{$\Psi$}

JEROME HALL LAW LIBRARY

INDIANA UNIVERSITY

Maurer School of Law
Bloomineton 


\title{
Fractured Territories and Abstracted Terrains: Human Rights Governance Regimes Within and Beyond the State
}

\author{
LARRY CATÁ BACKER ${ }^{*}$
}

\begin{abstract}
The problem of representation has become a central element for the development of human rights norms, not just within international organizations, but within states as well. The problem has been made acute by two significant changes in the organization of power that became visible after the 1950s. On one hand, the idea of the individual became more abstract. Mass democracy became symptomatic of a general trend toward the dissolution of the individual within a mass population, which was incarnated as the aggregation of its group characteristics, its statistics, and data. On the other hand, states were becoming less solid; the constitution of states, and of state power, formerly quite distinct in their forms and secure within their territories, gave way to a polycentric order in which national territory no longer defined and contained a compulsory and singular legal order sitting atop a hierarchy of governance. These two trends have had a noticeable impact, not just on law and governance generally, but more importantly, on the way that representation is understood and practiced. Today, the representation of individuals has become more problematic at the national level as it gives way to other bases of sovereign power derived from international norms. At the international level the individual loses representative capacity. The will of the consensus of states has supplanted that of the citizens of the state in ways that may undermine the legitimacy of governance systems. This paper considers the problem of representation within these

* Larry Catá Backer, W. Richard and Mary Eshelman Faculty Scholar \& Professor of Law, Professor of International Affairs, Pennsylvania State University. First presented at the Global Human Rights Law and the Boundaries of Statehood Colloquium hosted by the Stellenbosch Institute for Advanced Study, Stellenbosch, South Africa; conveners Hans Lindahl and Daniel Augenstein, March 21, 2015. My thanks to Professors Lindahl and Augenstein and the colloquium participants for both lively discussion and excellent comments.
\end{abstract}

Indiana Journal of Global Legal Studies Vol. 23 \#1 (Winter 2016)

(C) Indiana University Maurer School of Law 
intertwined phenomena. To that end, the paper considers the manifestation of these two macrotrends in the context of the governance of global business and human rights regulatory regimes. In the context of the first trend, the problem of who legitimately represents is considered within international organizations producing norms for transposition to the domestic legal orders of states. The specific context will be the public forums of the U.N. Working Group on Business and Human Rights. In the context of the second, the problem of what is the object of representation is considered at the national level, now the site of transposition of international norms. The specific context is the rise of multiple legal regimes each with a fidelity to a distinct representational community. The boundaries of statehood have been redefined and with them the nature and object of representation. Where states once existed, territories serve as "bowls" in which several national legal orders may operate through individuals and entities. Where international organizations once served the community of states, they now serve as vessels that contain mass interests re-incarnated as representative organizations that produce or negotiate formal law and societal norms for self-application. Within this context, simpleminded projects, and in particular the move toward a single comprehensive public law treaty on business and human rights, becomes an anachronistic exercise.

\section{INTRODUCTION}

Tyrant, avoid my sight,

Monster compact of spite, Who rules by fear and force!

None can deserve a throne

Who worships hate alone, Whose heart knows no remorse. ${ }^{1}$

In Handel's opera Giulio Cesare in Egitto, these words are uttered by a disgusted Caesar, Rome's leader, to the representatives of Ptolemy, mere king of Egypt, who, to court favor, presented Caesar with the severed head of Pompey Magnus, who had sought sanctuary in Egypt, oblivious to the fact that the Roman leaders, Caesar and Pompey, had reconciled. The decapitation of a Roman by an Egyptian on Egyptian soil sets in motion a course of events that eventually results in the

1. George Frideric Handel, Julius Caesar IN EGYPT, act 1, sc. 1 (Feb. 1724) (original translation: "Empio, dirò, tu sei, togliti a gli occhi miei, sei tutto crudeltà. Non è da re quel cuor, che donasi al rigor, che in seno non ha pietà.") (quoted in Janet Baker, 'Tyrant, Avoid My Sight', JANET BAKER SingS FROM JULIUS CAESAR (Brian Trowell, trans., Chandos Record 2002)). 
representative of Rome deposing the king and incarnation of Egypt, ${ }^{2}$ installing another more to his liking. The aria, and the underlying story, brings vividly to life the traditional and customary understanding, the power and complexity, of representation and legitimacy within governments, themselves arranged within hierarchies of power. Legitimacy fuels the outrage of Caesar. Tyranny, monstrosity, fear, force, etc., are all markers of illegitimate governance, the practice of which strips Ptolemy of authority ${ }^{3}$ - for authority is lacking in those who do not legitimately represent. ${ }^{4}$ Together, these normative constraints, complicated by their operation within multilevel authority structures, present a great challenge to the organization and implementation of power in contemporary emerging global orders.

This challenge is the central element of this essay: the problem of representation and legitimacy, of who serves which volonté générale. ${ }^{5}$ This problem now haunts national, and increasingly international, public and private institutions that seek to wrap their actions in the legitimacy of "representation" to assert authority on behalf of an aggregation of represented "others." This essay considers how the boundaries of statehood and of the reconstitution of sovereign authority in the mass state have transformed representation, both as to the representative herself (who is legitimately representative?) and as to the persons and things being represented. This essay approaches this inquiry by considering legitimacy and representation within a grid bounded by the changing nature of the individual represented and by

2. Cf. ERnSt H. Kantorowicz, The King's Two Bodies: A Study IN Mediaeval POLITICAL THEOLOGY (1957) (discussing the medieval political idea of the king's dual existence in both a physical realm and a spiritual realm-whereby the king's spiritual "body" would continue to represent his right to rule beyond his departure from the physical realm).

3. The U.S. Declaration of Independence provides a legal-political application of the sentiments compressed within the aria. See THE DECLARATION OF INDEPENDENCE (U.S. 1776).

4. See, e.g., DeClaRATION OF HUMAN AND Civic Rights OF 26 AUguSt 1789, art. 6 (1789) (Fr.), available at http://www.conseil-constitutionnel.fr/conseil-constitutionnel/root/ bank_mm/anglais/cst2.pdf ("The Law is the expression of the general will. All citizens have the right to take part, personally or through their representatives, in its making. It must be the same for all, whether it protects or punishes.").

5. The general will is understood both in its continental sense, consolidated, though by no means limited, to the conception articulated by Rousseau, see, e.g., JEAN-JACQUES Rousseau, Discourse on Political Economy, in ON THE SocIal CONTRACT: DISCOURSE ON THE ORIGIN OF INEQUALITY, DisCOURSE ON POLITICAL ECONOMY 163, 163-190 (Donald A. Cress ed. and trans., Hackett Publishing 1983) (arguing that the political state is conflicted in its service to the general will of the people by its duty to maintain its own well-being), as well as in the Anglo-American sense of consenting to devolve power to a government in which that power is fractured, see, e.g., ROBERT A. DAHL, A PREFACE TO DEMOCRATIC THEORY (1956). 
the changing environment of the national representative, both of which affect the capacity of particular persons or institutions to represent, and the scope and character of what is to be represented.

Part I briefly sets out a context within which to consider the problem of representation in the construction of global business and human rights norms. That context identifies two of the normative and structural trends within which representation is understood and the markers of legitimacy are attested. The first is the changed character of the individual, who is being transformed from person to data and from autonomous individual to part of an aggregated mass. The second is the changed character of the representation, from a focus on the popular will, however defined and identified, to an obligation of fidelity to an international normative will developed through public and private functionally differentiated organizations.

The essay considers the effect of fracture and reconstitution on representation in the context of the governance of business and human rights regulatory regimes, ${ }^{6}$ and principally the framework developed through the United Nations (U.N.) Guiding Principles for Business and Human Rights (UNGP). ${ }^{7}$ It examines recent efforts toward extending and harmonizing global regimes of business and human rights governance as they manifest within emerging governance orders inside and beyond the state. Part II looks to the representation of individuals and communities within international public and private governance orders, which have effects within the domestic orders of states but also constitute nonterritorial governance communities beyond the state. Its focus is the legitimacy-challenging issue of representation within these fractured territories of nonstate governance orders whose borders are neither fixed nor physical. To that end, the paper considers the rise of nonstate organizations where the governance of business is negotiated. The specific context will be the public forums of the U.N. Working Group on Business and Human Rights. ${ }^{8}$

Part III examines the challenge of representation as the crucial destabilizing force for representational legitimacy in its second aspectthe representation of law within states whose engagement with law is now complicated by the logic of the emerging global system of public and

6. See generally SuRYa DEVA, REgulating CoRPoRate Human Rights Violations: HUMANIZING BUSINESS 152-200 (2012) (discussing the human rights standards that multinational corporations should apply in their operation and also the manner in which companies can be made accountable for violations).

7. See Special Representative of the Secretary-General, Guiding Principles on Business and Human Rights: Implementing the United Nations "Protect, Respect and Remedy" Framework, U.N. Doc. HR/PUB/11/04 (2011) [hereinafter Guiding Principles on Business].

8. See infra Part III. 
private governance. ${ }^{9}$ Its focus is the legitimacy-challenging issue of representation in these abstracted terrains of the contemporary state, which receive, as an abstracted general will of the international community, the norms of nonstate governance orders in which the individual is only abstractly represented. In this context, the paper considers the extent to which the laws of multiple domestic legal orders may operate simultaneously within a state. The specific context will be the Republic of Bangladesh and the regimes of domestic and international governance for business and human rights to which it is subject. In Bangladesh, multiple regimes of governance rules for the human rights conduct of business operate simultaneously, as multinational enterprises (MNEs) and their value-chain partners may be subject simultaneously to national law, the laws of the home state of the controlling enterprise (often resident in China or in a member-state of the Organisation for Economic Co-operation and Development (OECD)), and the special regimes of bilateral and multilateral treaties on investment and taxation. The Bangladeshi citizen is faced with multiple representations, all of which assert authority over her life, and few of which represent her. Each, though, might claim to act for her or on her behalf. The European Union, representing its Member States and their citizens, may exercise authority over enterprises operating in Bangladesh, including regulation of the relationship between these entities and those residents in Bangladesh. The enterprises themselves, representing their shareholders and customers, may assert authority over the Bangladeshi's employer and determine the quality of the conditions in which she works and lives. Groups of enterprises representing industry may assert authority to determine standards (for example, for building inspection of factories) that are true to international standards and are imposed on Bangladesh. Accords reached with the United States and the European Union, each representing their respective populations, may compel Bangladesh to reform its labor laws to conform to standards deemed legitimate without a corresponding consensus among the Bangladeshi population. The legal territoriality of Bangladesh, then, becomes a far more complex terrain than its geographic borders might suggest. One sees clearly here the consequences of the operation of global markets on the organization, identity, and authority of general will, complicating representation in

9. Cf. Daniel Augenstein \& David Kinley, When Human Rights 'Responsibilities' Become 'Duties': The Extra-territorial Obligations of States that Bind Corporations, in HuMAN Rights OBLIGATIONS OF BUSINESS: BEYOND THE CORPORATE RESPONSIBILITY TO REsPeCT? 271 (Surya Deva \& David Bilchitz, eds., 2013) (discussing the distinction between "direct extra-territorial jurisdiction" and "domestic measures with extraterritorial implications"). 
the face of distinct communities asserting authority and effectively inverting the issue of representation and legitimacy. The consequences for the legitimacy of law are profound. Law is domestically legitimate only to the extent that it embodies a variable set of the general will of communities beyond the state but acting within it. Mass democracy is legitimate only in conformity to this higher popular will.

\section{The Problem of Representation}

Decades before it was solidified as political theory by Enlightenment elites, ${ }^{10}$ the issue of representation, even within the context of eighteenth-century European absolute monarchies, ${ }^{11}$ was understood as a foundational societal value grounded in custom and tradition so well understood that it appears as a commonplace in opera libretti. This is sometimes expressed in the idea of normative constraints on communal will. ${ }^{12}$ Much of the edifice of human rights is built on this notion. ${ }^{13}$

Modern theory conceives of representation as variations of operationalization of a social contract, ${ }^{14}$ grounded in consent, ${ }^{15}$ and, at

10. See, e.g., Patrick Riley, The General Will Before Rousseau, 6 POL. THEORY 485, 48586 (1978) (tracing the idea of the general will from Montesquieu to Rousseau).

11. This is not just limited to European absolutist monarchies of the 17th-18th centuries. The concept of the "mandate of heaven" and its revocation are related. See Dingxin Zhao, The Mandate of Heaven and Performance Legitimation in Historical and Contemporary China, 53 AM. BEHAV. SCIENTIST 416, 416 (2009) ("Performance legitimacy, an aspect of state legitimacy neglected by Weber in his original formulation of the theory of domination, played a particularly important role in the history of China and has shaped not only the patterns of Chinese history but also today's Chinese politics."). There are Biblical resonances as well. See 1 Samuel 15:1-34 (describing God stripping Saul of kingship over Israel when he failed to obey Divine will). In both Chinese and Biblical kingships, the emperor or king represented the Divine Will on Earth; the failure to appropriately represent it precipitated the loss of legitimacy to rule.

12. See Larry Catá Backer, God(s) Over Constitutions: International and Religious Transnational Constitutionalism in the 21st Century, 27 MIss. C. L. REv. 11, 24-37 (2008) (describing transnational constitutionalism as a mechanism of control of national popular will).

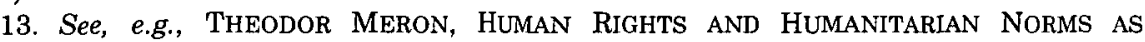
INTERNATIONAL CUSTOMARY LAW (1989) (examining the relationship between human rights norms and customary laws in states and in the international forum).

14. See, e.g., JoHN LOCKE, THE SECOND TREATISE OF GOVERNMENT: AN ESSAY Concerning the True Original, Extent, and End of Civil Government (1689), reprinted in Political Writings 261, 309-323 (David Wootton ed., Hackett Publ'g 1993); see also JoHN DUNN, THE POLITICAL THOUGHT OF JOHN LOCKE: AN HistoriCAL ACCOUNT OF THE ARGUMENT OF TWO TREATISES OF GOVERNMENT (1969) (advancing a historical interpretation of Locke's Second Treatise). 
least with respect to the operation of the legislative and administrative branches of government, usually on a fidelity to the constraints of legitimacy bounded by an application of a volonté génénale, a general will. ${ }^{16}$ Together these constitute the contemporary basis of the legitimacy of public power by grounding it as a representative exercise..$^{17}$ That consensus makes it as clear to the audiences of Handel's day as it does for contemporary polities, that tyranny (arbitrary government) can lose its legitimacy and thus its entitlement to rule when it ceases to serve. ${ }^{18}$ Yet that basis of mass democracy grounded in the general will and exercised through the representative organs of government continues to discomfit modern political organization and its theorists. ${ }^{19}$

That discomfiture arises with respect to two challenges. The first is the challenge of locating the object of representation (that is, who or what is represented?). The second is the challenge of the identity of the representative (that is, who can adequately represent those in whose name authority is exercised?). In most modern republics, prevailing institutional political expression frames these challenges, ${ }^{20}$ often in the quasiconstitutional documents of states. ${ }^{21}$ But that institutional expression of a normative organizational baseline for legitimate exercise

15. See, e.g., W.T. Jones, Rousseau's General Will and the Problem of Consent, 25 J. HIST. PHIL. 105, 106 (1987) (examining how consent is an essential part of political morality and the general will).

16. See, e.g., Ramon Flecha \& Marta Soler, Communicative Methodology: Successful Actions and Dialogic Democracy, 62 CURRENT Soc. 232, 232-235 (2014) (describing how a sociological study sanctioned by the European Parliament achieved the acceptance and political representation of the Roma people in Spain).

17. Despite the obvious temptation, this essay will not lose itself within the fascinating and unfinished work of understanding, critiquing, defending, or faithfully applying some version of what might be labeled a general will derived from, through, or around the work of Rousseau and his contemporaries. For that, there is a mountain of Rousseau and related scholarship. See, e.g., JEAN-JACQUES ROUSSEAU: CRITICAL ASSESSMENTS OF LEADING Polittcal Philosophers (John T. Scott, ed., Routledge, 2006); Tracy B. StTrong, JfanJACQUES ROUSSEAU: THE POLITICS OF THE ORDINARY (1994); MAURIZIO VIROLI, JEAN-JACQUES ROUSSEAU AND THE 'WELL-ORDERED SOCIETY' (Derek Hanson trans.) (1988).

18. Cf. Weigang Chen, Confucian Humanism and Theodicy, 80 J. AM. ACAD. RELIGION 932, 942 (2012) (claiming that a governing force is only legitimate if it possesses sufficient merits as determined by the people).

19. Compare J. L. TALMON, I THE ORIgins of Totalitarian DEMOCRACY (1952), and J. L. TALMON, II THE ORIGINS OF TOTALITARIAN DEMOCRACY (1960) (discussing collective will as the basis for "totalitarian democracy" characterized by pursuit of collective purpose), with THE FEDERalisT No. 10 (James Madison) (claiming that majority tyranny and structural fracture contain communal will in polyarchal democracy).

20. For a prescient discussion, see EDWARD HALlETT CARR, NATIONALISM AND AFTER 38-70 (1945).

21. This is nicely framed by the French Declaration of Human and Civic Rights, DEClaRATION OF HuMAN AND CIVIC RIghts of 26 August 1789, art. 6 (1789) (Fr.), where one notes the connection to the sovereign will. 
of power is itself challenged by the pull of a representative's fidelity, not to a general will grounded in a population represented, ${ }^{22}$ but to an institutional or normative will whose representation might override any fidelity to the wishes of a represented population, ${ }^{23}$ or sometimes even to custom and tradition. ${ }^{24}$ This, of course, touches on solidarity, ${ }^{25}$ beyond the usual complexities of multiple fidelities to people, law, and constitution common to elected officials in representative democracies. ${ }^{26}$ The twentieth century suggested a hierarchy of fidelity to these volontés générales even within the construction of a state, in which religious values, ${ }^{27}$ natural law, ${ }^{28}$ and jus gentium ${ }^{29}$ all jostled for a place within a hierarchy whose engine was the national government. ${ }^{30}$

22. See, e.g., David Stadelmann et al., Quantifying Parliamentary Representation of Constituents' Preferences with Quasi-Experimental Data, 41 J. COMP. ECON. 170 (2012) (studying the relation between the actions of political representatives with the voting preferences of their constituents in the Swiss referendum process).

23. See, e.g., Travis Gettys, NC Republican Reveals His 'Primary Mission' as Congressman: 'We're Here as Emissaries for Christ', RAWsTORY, July 14, 2015, http://www.rawstory.com/2015/07/nc-republican-reveals-his-primary-mission-as-

congressman-were-here-as-emissaries-for-christ ("Pittenger said his chief priority as an elected official was to promote Christianity to voters and other lawmakers. 'That's my primary mission as a member of Congress,' he said. 'Yes, to serve my constituents, to serve my region, and my state, and my country-but we're here as emissaries for Christ."').

24. The notions are nicely illustrated in JOHN F. KENNEDY, PROFILES IN COURAGE (1956) (demonstrating examples of individuals who had the courage to remain loyal to higher ideals in their political lives irrespective of the pressures of popular demands).

25. See generally HaUke BRUnkhorst, Solidarity: From Civic Friendship To A Global Legal Community (Jeffrey Flynn trans., MIT Press 2005) (examining the bond between free citizens in the context of international law).

26. See Sheila Kennedy and David Schultz, American Public Service: CONSTITUTIONAL AND ETHICAL FOUNDATIONS 108-14 (2011).

27. See, e.g., Martin E. Marty, Protestantism in the United States: Righteous EMPIRE 177-266 (2d ed. 1986) (describing Protestant experience in the 20th century); see generally, A. JAMES REICHLEY, RELIGION IN AMERICAN PUBLIC LIFE 219-338 (1985) (discussing the political and public expression of America's diverse religious beliefs); James Davison Hunter, Law, Religion, and the Common Good, 39 PEPP. L. REv. 1076 (2013).

28. See, e.g., John FinNis, NATURAL LAW AND NATURAL RIGHTs (2d. ed. 2011) (offering a natural law theory framework that integrates questions in ethics, politics and jurisprudence). See generally EDWARD S. CORWIN, THE "HIGHER LAW" BACKGROUND OF AMERICAN CONSTITUTIONAL LAW (Cornell Univ. Press 1955) (1928) (explaining natural law's shaping of American society).

29. See, e.g., ANTônio AUgusto CANÇAdo TRINDAdE, INTERNATIONAL LAW For HumankIND: TOWARDS A NEW JUS GENTIUM (2d rev. ed. 2013) (examining the current humanization and universalization of the law of nations); Edwin D. Dickinson, The Law of Nations as Part of the National Law of the United States, 101 U. PA. L. REV. 26, 27 (1952) (arguing for the heritage of jus gentium in the United States).

30. See Larry Catá Backer, From Constitution to Constitutionalism: A Global Framework for Legitimate Public Power Systems, 113 PENN ST. L. REv. 671, 676 (2009). 
Ordering, managing, and working within this marketplace of general wills posed the deepest challenge to the state, and especially to the legitimate expression of government that is representative of its people both in the enactment and in the implementation of law produced through the organs of state. Representativeness suggests a notion both of legitimacy in consensus and of the nature of representation in political institutions. With the end of the Second World War, the victorious states, though divided into three camps defined by ideology and colonial relations, all sought to strive toward a consensus with respect to the normative framework within which human organization could be structured. ${ }^{31}$ That consensus started with the dismantling of the old colonialist ideology and the construction of a new global order founded on the formal equality of states. ${ }^{32}$ It affirmed the preeminence of politics over societal and economic regimes as the basis for the operationalization of this emergent normative framework. ${ }^{33}$ Lastly, it embraced law as the most legitimate vehicle through which operationalization could be manifested, both as the expression of rules and as the basis for systems of compulsion, discipline, and remediation. ${ }^{34}$

Nearly half a century ago, Michel Foucault noticed two significant changes in the organization of power. ${ }^{35} \mathrm{On}$ one hand, states were becoming less solid; the constitution of states, and of state power, formerly quite distinct in their forms and secure within their territories, were giving way to a polycentric order in which national territory no longer defined and contained a compulsory and singular legal order sitting atop a hierarchy of governance. The command-based regimes of law, proceeding from the monarch or his successors in modern democratic states, was increasingly augmented by the disciplines of soft

31. See Larry Catá Backer, God(s) Over Constitutions: International and Religious Transnational Constitutionalism in the 21st Century, 27 MISS. C. L. REV. 11, 28-9 (2008) (discussing roughly liberal democracies, Marxist-Leninist states, and theocratic states).

32. See U.N. Charter art. 2, para. 1, available at $\mathrm{http}: / / \mathrm{www} . u n . o r g / e n / d o c u m e n t s /$ charter ("The Organization is based on the principle of the sovereign equality of all its Members.").

33. See id. at art. 1, para. 3 ("To achieve international co-operation in solving international problems of an economic, social, cultural, or humanitarian character, and in promoting and encouraging respect for human rights and for fundamental freedoms for all without distinction as to race, sex, language, or religion ....").

34. See generally Gralf-Peter Calliess \& PeEr Zumbansen, Rough Consensus and Running Code: A Theory of Transnational Private LaW (2010) (discussing the relationship between law and social norms).

35. See Michel Foucault, Security, Territory, Population: Lectures at the COLLÈGE DE FranCE, 1977-1978, at 87-114 (Michel Senellart et al. eds., Graham Burchell trans., 2007). 
power, and ultimately of biopower. ${ }^{36}$ Yet soft power itself was a technique-a new means of insinuating one of any number of competing general-will structures on and through a population ${ }^{37}$ that itself now served both as the legitimating basis of power-exercises and as the object on which they were practiced.

That shift both to soft power and to the population as simultaneously object and method has also changed the character of the object represented-from one focused on the individual to one focused on the mass, and then from one focused on the mass to one focused on conceptual frameworks. Indeed, the changes in the relations between individual, norm, state, and law also produced effects on individuals. The autonomous individual, a vessel for a host of rights and duties, was becoming more abstract. The individual became insignificant in the face of the mass of individuals that served as the fuel of the legaldisciplinary mechanisms of state power. She became important only as a point of data-a source of harvestable information from which the new aggregated individual emerged: the population. ${ }^{38}$ Mass democracy became symptomatic of a general trend toward the dissolution of the individual within the masses. Within this reconstruction, the individual acquired significance only as a subpart of the population, which in turn was incarnated as an aggregation of the group and its characteristics, statistics, and data. This was particularly apparent in the availability of remedies for adverse human rights impacts that might affect individuals within a population, and the availability of venues for popular participation in the regulation of such adverse human rights impacts. The individual disappears and is reconstituted as a population-the focus of individual rights is transposed onto aggregations of individuals. The individual no longer speaks for herself to any appreciable extent, especially within discourses of human rights in economic matters; she speaks only through institutionalized individuals-the state, the nongovernmental organization, the institutional voices of religion, or the multinational enterprise.

The problem of representation and legitimacy becomes a central element here as well, but in a distinctive way. The representative, whether exercising power internally within states or among states in the international sphere, must first seek the object of representation and then discern and apply its higher order (general) will. The legitimacy of the representative herself, however, will depend on her

36. See 1 Michel Foucault, The History of Sexuality 91-110 (1990) (Robert Hurley trans., Vintage Books ed. 1990) (discussing the management of economic and reproductive productivity through the organization of society).

37. See FouCAULT, supra note 35 , at 87-114.

38. See id. 
capacity to represent, directly or indirectly, that object from which her representative power derives. These two critical challenges of representation-the question of whose will must be represented within states, and the authenticity of representation by those who seek to speak on behalf of the individual domestically and in the international sphere-converge within the fractured governance territory of globalization, and are particularly acute in the context of the governance of economic activity within global chains of production.

The result is representational perversity and a more subtle double form of potential delegitimation, which becomes particularly acute in the framing of governance rules for the human rights effects of economic activity. Norms and principles are elaborated among states where individuals are at best indirectly, and often indifferently, represented. Those norms and principles are then applied within the domestic legal orders of states in which the authority of mass preference is subordinated to the general will reflected in supranational norms and principles now embedded within domestic legal orders. Polyarchal democracy ${ }^{39}$ contributes to the tendency to subsume the individual within faction, ${ }^{40}$ and factions as contributors to the general will of the people expressed through the mediating principles of constrained majoritarianism. ${ }^{41}$ People, as individuals or citizens, now abstracted and denatured, are effectively removed from a human-rights enhancing project undertaken on their behalf but without their participation. The cover of formal connection between democratic national institutions and this governance project does little to enhance the functional effects of disconnected representation.

The consequence? Perhaps that monster compact of spite, who may not deserve its throne, ${ }^{42}$ suggests the difficulties of legitimation of human rights regimes decentered from sources of representational legitimacy. Or it may suggest the monstrosity of people and the need for greater fidelity to representation of higher-level concepts, leaving to the masses only a limited range of implementation options. Where states once existed, their territories now contain multiple legal orders, and

39. See DAHL, supra note 5, at 63-89.

40. See generally THE FEDERALIST NOS. 10, 14 (James Madison) (describing the dangers of faction).

41. See, e.g., Alexander M. Bickel, The Least Dangerous Branch: The Supreme Court at THE BAR of Politics 16-23 (1962); Susanna Mancini, The Crucifix Rage: Supranational Constitutionalism Bumps Against the Counter-Majoritarian Difficulty, 6 EUR. CONST. L. REv. 6, 24-7 (2010); Gabriel J. Chin \& Randy Wagner, The Tyranny of the Minority: Jim Crow and the Counter-Majoritarian Difficulty, 43 HARV. C.R.-C.L. L. REV. 65, 67 (2008) ("The counter-majoritarian difficulty posits that laws are presumptively legitimate as the fruit of the democratic process and majority will.").

42. See HANDEL, supra note 1. 
their legal territories are now divided among the abstract territories of enterprises, organizations, and states that may operate within or through their territories. Where individuals once existed as autonomous political actors, their autonomy has migrated to representative bodies and individual autonomy becomes a residual rather than a primary value of social and political organization. International organizations now not only serve the community of states, but also serve as vessels that contain mass interests reincarnated as representative organizations that produce or negotiate formal law and societal norms for self-application. Within this context, simpleminded projects, exemplified by moves toward a single comprehensive public law treaty on business and human rights, become an anachronistic exercise significantly removed from the realities of law and population in this century. A purely state-centered conception of international human rights law is dead.

\section{FRACTURED TERRITORIES: REPRESENTING THE INDIVIDUAL IN THE GLOBAL SPHERE}

There appears to be a tradeoff of sorts within the political sphere. This tradeoff is grounded in the centrality of mass democracy as the foundation of all public legitimacy. Where there is a direct connection, however flawed, between individuals in a community and their representatives, those representatives may assert greater authority to enact and enforce commands (usually through law or regulation). That, of course, is the basis of modern constitutionalism ${ }^{43}$ and the legitimacy of government. ${ }^{44}$ Those commands, that law, are maximally compulsory when enacted through systems in which public power has been devolved in this manner. ${ }^{45}$ Conversely, in the absence of such direct connections

43. See Robert Schütze, From Dual to Cooperative Federalism: The Changing STRUCTURE OF EUROPEAN LAW 80-94 (2009) (detailing the decline of constitutional exclusivity in post-1937 United States). See generally K. C. WhEARE, MODERN CONSTITUTIONS (1951).

44. See, e.g., Organization of American States, Inter-American Democratic Charter art. 1, September 11, 2001, KAV 7230 ("The peoples of the Americas have a right to democracy and their governments have an obligation to promote and defend it."). The representational character of democratic ordering is also well understood: "The effective exercise of representative democracy is the basis for the rule of law and of the constitutional regimes of the member states of the Organization of American States. Representative democracy is strengthened and deepened by permanent, ethical, and responsible participation of the citizenry within a legal framework conforming to the respective constitutional order." Id. at art. 2.

45. "It is the right and responsibility of all citizens to participate in decisions relating to their own development. This is also a necessary condition for the full and effective exercise of democracy." Id. at art. 6. 
between individuals governed and the apparatus of those seeking to govern, the authority to directly enact and compel obedience to rule (however denominated) shrinks to practically nothing.

The operation of international law and its relation to domestic legal orders reveal these poles in contemporary political structures. National law is compulsory to the extent that it is legitimate, and it is legitimate to the extent that it is appropriately enacted through the mechanisms provided by those in whom representational authority has been vested. International law, on the other hand, indirectly connected to representational sources, is only indirectly applicable-it requires in many jurisdictions a national act to transpose it from an obligation of the state to one of general applicability. The direct connection between a government and its citizens was at the core of the issue of legitimacy for the American republic from its outset ${ }^{46}$ and has been an important element in strengthening the legislative legitimacy of the European Union. ${ }^{47}$

This set of relationships is easy enough in the context of conventional states or federal systems. But the individual loses coherence as an element of mass democratic organization where the polity falls away. In that context two questions arise--how does one connect individuals to the mechanisms of norm or governance creation, and who legitimately represents that individual thus constituted? These issues become central to the problem of the authenticity and legitimacy of international norm-making, which seeks to move beyond its role as second-order rules (soft law) and have a more legitimately binding character. This is a problem especially acute in the context of the organizational structures for norm-making that were established in the wake of the endorsement of the UNGP.

With the U.N. Human Rights Council's (HRC) 2011 endorsement of the UNGP for implementing the U.N. "Protect, Respect and Remedy" Framework, ${ }^{48}$ the HRC introduced a global standard for preventing and addressing the risk of adverse impacts on human rights linked to

46. See, e.g., Marbury v. Madison, 5 U.S. 137, 176 (1803); cf. Bundesverfassungsgericht [BVERFG] [Federal Constitutional Court] Oct. 12, 1993, 89 Official Court Reports 155 (Ger.), available at http://www.judicialstudies.unr.edu/JS_Summer09/JSP_Week_1/ German\%20ConstCourt\%20Maastricht.pdf.

47. This was bound up in the evolution of the European Parliament. "The European Parliament is an important forum for political debate and decision-marking at the EU level. The Members of the European Parliament are directly elected by voters in all Member States to represent people's interests with regard to EU law-making and to make sure other EU institutions are working democratically." EUROPEAN PARLIAMENT, About Parliament: Welcome to the European Parliament, http://www.europarl.europa.eu/about parliament/en (last visited Oct. 10, 2015).

48. See Guiding Principles on Business, supra note 7. 
business activity. The UNGP are framed as three related governance regimes or "pillars." 49 The first pillar defines the state's duty to protect human rights, a duty grounded in the international obligations of states. The second pillar requires corporate responsibility to respect human rights, grounded in the role of business as a specialized organ of society. The third pillar defines an obligation to provide effective remedies for breaches of human rights and seeks to match rights and obligations to effective remedies. The object was to frame a polycentric and interlinked governance structure, ${ }^{50}$ constructed around consensus standards for business and human rights. ${ }^{51}$

As part of the mandate of the Office of the High Commissioner for Human Rights (OHCHR) to lead the business and human rights agenda within the U.N. system and to further elaborate the UNGP and their operationalization, in 2011, the HRC established a "Working Group on the issue of human rights and transnational corporations and other business enterprises." 52 This Working Group, consisting of five independent experts of balanced geographical representation, ${ }^{53}$ had its mandate renewed for a three-year term in $2014 .{ }^{54}$

The Working Group has become the center of the focus of international public and private actors on the formal elaboration and operationalization of the normative principles that are at the heart of the UNGP, ${ }^{55}$ and to do so both through action at the state level ${ }^{56}$ and

49. Id. at 1.

50. Cf. Bruce L. Benson, Polycentric Governance, Cato Unbound (Aug. 16, 2007), http://www.cato-unbound.org/2007/08/16/bruce-l-benson/polycentric-governance; Mark B. Taylor, The Ruggie Framework: Polycentric Regulation and the Implications for Corporate Social Responsibility, 5 NORDIC J. APPLIED ETHICS 9, 21-22 (2011).

51. See John Gerard RugGie, Just Business: Multinational Corporations and HuMAN RIGHTS 37-80 (2013).

52. See G.A. Res. 17/4, ๆ 6, U.N. Doc. A/HRC/RES/17/4 (July 6, 2011).

53. Working Group on the Issue of Human Rights and Transnational Corporations and Other Business Enterprises, UNITED NATIONS OFFICE OF THE HIGH COMM'R FOR HUM. RTS., http://www.ohchr.org/EN/Issues/Business/Pages/WGHRandtransnationalcorporationsando therbusiness.aspx (last visited Oct. 20, 2015).

54. Id. (citing Human Rights Council Res. 26/22, Human Rights and Transnational Corporations and Other Business Enterprises, 26th Sess., June 10-27, 2014, U.N. GAOR, 69th Sess., Supp. No. 53, A/69/53, at 187-90 (June 27, 2014), available at http://daccessdds-ny.un.org/doc/UNDOC/GEN/G14/142/68/PDF/G1414268.pdf?OpenElement).

55. The mandate of the Working Group is broad and includes the following: the promotion of the UNGP; the promotion of good practices from the implementation of the UNGP; capacity building; monitoring through country visits; making recommendations to improve the remedial function; the integration of a gender perspective throughout the work of the mandate; the coordination with other U.N. special procedures; to develop dialog within the U.N.'s organization; to guide the work of the Forum on Business and Human Rights; and to prepare annual reports to the Human Rights Council and the General Assembly. See id. 
within the global social sphere. ${ }^{57}$ It oversees what has become one of the most important gatherings of global representatives of interested stakeholders and stakeholder factions that have arisen around the issues of business and human rights since the 1970s, the Forum on Business and Human Rights held annually in Geneva. 58 The Forum is a self-styled "space for representatives and practitioners from civil society, business, government, international organizations and affected stakeholders to take stock of challenges and discuss ways to move forward on putting into practice the Guiding Principles on Business and Human Rights." 59

The Forum has grown dramatically since its beginning in 2012 . The Forum is an important venue for informal networking among the mass of civil society organizations involved in the business of human rights, and for states and large business enterprises to signal their intentions. Indeed, the importance of the function of the Forum was recognized by the Human Rights Council in extending the Working Group's mandate in $2014 .{ }^{60}$

The Forum on Business and Human Rights has been an important site, not only for debate about the evolution and application of the UNGP, but also as a critical venue where stakeholders may engage in the sort of factional politics that produce sometimes-substantial movements in the activities and objectives of international organizations. Perhaps the most important of such movements was the factional effort that culminated in the creation of an intergovernmental working group to elaborate an international, legally binding instrument

\footnotetext{
56. See infra Part IV (discussing the Working Group's consequences for representation).

57. This focuses on the so-called second pillar: the responsibility to respect human rights and the human rights due diligence responsibilities of business enterprises. See generally Larry C. Backer, From Institutional Misalignments to Socially Sustainable Governance: The Guiding Principles for the Implementation of the United Nation's "Protect, Respect and Remedy" and the Construction of Inter-Systemic Global Governance, 25 PAC. MCGEorge Global Bus. \& DeV. L.J. 69.

58. See G.A. Res. 17/4, supra note 52, I 12 (establishing a Forum on Business and Human Rights to discuss trends and challenges in the implementation of the Guiding Principles and promote discussion and cooperation on business and human rights issues).

59. The 4th Annual United Nations Forum on Business and Human Rights, UNITED NATIONS OFFICE OF THE HIGH COMM'R FOR HUM. RTS., http://www.ohchr.org/EN/Issues/ Business/Forum/Pages/2015ForumBHR.aspx (last visited Sept. 10, 2015).

60. Human Rights Council Res. 26/22, Human Rights and Transnational Corporations and Other Business Enterprises, 26th Sess., June 10-27, 2014, U.N. GAOR, 69th Sess., Supp. No. 53, A/69/53, at 187-90 (June 27, 2014), available at http://daccess-ddsny.un.org/doc/UNDOC/GEN/G14/142/68/PDF/G1414268.pdf?OpenElement ("[T]he annual Forum on Business and Human Rights has grown in size and become a valuable opportunity for constructive global exchange of challenges, lessons learned and good practices in implementing the Guiding Principles by all relevant stakeholders ....”).
} 
on transnational corporations and other business enterprises with respect to human rights. ${ }^{61}$ Beyond developing strong networks and relationships among stakeholders, the Forum has become a body within which global social norms are crafted-or managed-with the object of changing expectations of legitimate conduct, enterprise behaviors in transnational space, and, more problematically, enterprise behaviors within the domestic legal orders of states. Within the Forum, particularly with respect to its role as a space for the generation of governance standards, influence is the coin of the realm (sometimes supported by status within the community of business and human rights participants). Indeed, influence is a necessary substitute within a governance organization where formal lawmaking is unavailable.

Yet the Forum's "space for representatives and practitioners" presents a set of curious challenges for representation, and for the construction of a representative body around the Forum itself. Both are intertwined in the organization of the Forum itself. The construct remains medieval, perhaps justifiably so in a community that is being constructed outside the parameters of state organization. The Forum remains an important gathering of a global estates general, ${ }^{62}$ a classbased representative body drawn from the three "estates" into which the "kingdom" of human rights society has been theoretically divided. But there is no crown in this kingdom; its three estates-business, civil society, and states-are given form and managed through the organization of the United Nations, which serves as a legitimating space within which this community can manifest itself. But these "estates general" are not institutionalized, nor has their work been routinized; their components remain-highly contested.

The three institutionally structured stakeholder estates ärē relatively easy to understand in representational terms. States represent themselves-and indeed, to the extent they find useful, every

61. See Human Rights Council Res. 26/9, Elaboration of an International Legally Binding Instrument on Transnational Corporations and Other Business Enterprises with Respect to Human Rights, 26th Sess., June 10-27, 2014, U.N. GAOR, 69th Sess., Supp. No. 53, A/26/9, I 1 (June 26, 2014), available at http://documents-ddsny.un.org/doc/UNDOC/GEN/G14/082/52/pdf/G1408252.pdf?OpenElement ("The human rights council . . . decides to establish an open-ended intergovernmental working group on transnational corporations and other business enterprises with respect to human rights; whose mandate shall be to elaborate an international legally binding instrument to regulate, in international human rights law, the activities of transnational corporations and other business enterprises.").

62. See, e.g., Owen Ulph, Note, The Mandate System and Representation to the Estates General Under the Old Regime, 23 J. MODERN HISTORY 225, 226 (stating that, from the 14th to 16th centuries, medieval society experienced a transformation whereby direct personal attendance and indirect attendance with proxies were replaced with representation through elected delegates). 
state can participate in the Forum, and their interests are thus directly represented. Business enterprises may also participate directly, and are represented by business associations. Civil society represents itself as well and can organize collective representation on an ad hoc basis. These three estates share common characteristics. Each is a body corporate, an aggregation of political, economic, or societal power which operates collectively. Each is an abstraction incarnated, inherently representational in its internal organization-states represent their citizens, enterprises their shareholders and owners, civil society its members. Each are representative in the sense that they represent themselves. In so doing they also represent their members, and to some extent they may be said to represent the members of their estates.

There is one "estate" whose presence is abstracted and only recognized indirectly-the individual. The resulting representational challenges become acute in two respects: first with respect to the constitution of the individual as a mass stakeholder, and second in the determination of the appropriate representative of this mass individual. The individual appears as an abstract composite of statistics, ${ }^{63}$ or as a symbolic victim extracted from particular occurrences, which members of the other estates seek to emphasize. ${ }^{64}$ The individual is increasingly a composite of the geographies of data, and the rights and remedial obligations of states and enterprises are increasingly understood in relation to these individuals reconstituted as aggregations of data with differentiable characteristics. ${ }^{65}$ But the individual does not appear as a represented force at the Forum.

The character of structures of norm-making at the international level may make direct engagement impossible. First, all stakeholders in such organizations are themselves aggregated composites-states, civil society, and enterprises are all bodies corporate with internal representational mandates. Second, participation in elite governance structures, especially in the transnational sphere, requires a certain discursive competence in the rules of interpersonal engagement and the boundaries within which discussion may occur and action may take place. It is impossible to expect the internalization of these sometimes

63. Cf. FOUCAULT, supra note 35 , at $87-114$.

64. That was made clear by the sadly post hoc intervention of indigenous people for a greater institutional role within the "estates general," either as an estate of their own or by the expansion of the project of business and human rights to embrace their agendas.

65. Cf. Stephen Legg, Foucault's Population Geographies; Classifications, Biopolitics and Government Spaces, 11 PoPUlation, SPACE, \& Place 137, 140-44 (2005) (arguing that Foucault's approach spans the individual and the state, but also combines a quantitative attention to statistics and numbers with a qualitative awareness of the contingent nature of categories and the processes they claim to expose). 
subtle and complex rules of individuals who are at the bottom of social, cultural, economic, and political hierarchies. ${ }^{66}$

The organizational logic of governance, then, suggests that the individual may be represented through the organizational stakeholders who comprise the estates general of governance organizations like the Forum on Business and Human Rights. Individuals and vulnerable communities are understood to be represented by states in accordance with their constitutional and sovereign obligations under principles of mass democracy. Individuals as part of the polity of states derive their power through the mechanisms of authentic representation within states, which they may, as a mass, hold accountable through election and within mechanisms for engagement with the action of officials and the constraints of law. Effective representation of individuals is increasingly the object of civil society actors. Civil society restructures polities along functionally differentiated interests. Each civil society organization is self-constituted, ${ }^{67}$ and operates in abstracted territories by representing its members and serving its objectives. ${ }^{68}$ Within these organizations, the individual is represented in the context of the interests and objectives served by the civil society apparatus. As there are many variants of civil society, so an individual may choose to embrace as many civil society organizations as she has the time, resources, and stomach for. In some respects, even enterprises may be said to represent individuals-particularly the investor and consumer communities on whom they entirely depend for their existence.69 Enterprises certainly serve the interests of these individuals in the context of the economic relations that bind investor and consumer to producer and enterprise.

But in all three cases there may be significant failures of representation. First, states may represent individuals within their

66. Cf. Andrew Rehfeld, Representation Rethought: On Trustees, Delegates, and Gyroscopes in the Study of Political Representation and Democracy, 103 AMER. POL. SCI. REV. 214 (May 2009) (arguing that the usual formulation of the debate surrounding the trustee/delegate problem collapses three distinctions-aims, source of judgment, and responsiveness-and obscures the underlying complexity of the phenomenon).

67. See, e.g., Gunther Teubner et al., Debate and Dialogue: Constitutionalizing Polycontextuality, 20 Soc. \& LEGAL STUD. 210, 210 (2011) ("Constitutional problems arise outside the limits of the nation-state in transnational politics and at the same time outside institutionalized politics, in the 'private' sectors of global society.").

68. See generally Dieter Grimm, The Constitution in the Process of Denationalization, 12 CONSTELLATIONS 447 (2005) (discussing the effects that denationalization has on state constitutions and their claims to comprehensively regulate political rule).

69. See Larry Catá Backer, Economic Globalization and the Rise of Efficient Systems of Global Private Law Making: Wal-Mart as Global Legislator, 39 CONN. L. REV. 1739, 175960 (2007) (noting that consumers' and investors' reactions to the actions of corporate and financial institutions act as approval of those actions). 
polity, but they do not represent the mass of individuals that comprise the global community of individuals with respect to whom international norms are developed. This is an important problem not merely of representation but of legitimacy. This problem was at the foundation of the first and quite powerful attack on the legitimacy of federal states and served as an essential impetus to grounding that legitimacy in direct connection and representation between governmental apparatus and individual. ${ }^{70}$ States may represent their polity, but they are incapable of representing the mass of individuals over which norms are constructed in the international sphere. It follows that this lack of direct connection between a state and the mass of people divided among the several states reduces the viability of state representation of the mass of individuals. More particularly, at the international level, states may feel obliged to further the undifferentiated interests of their governments, as a result of which individuals and their needs may be understood solely as matters of internal concern.

Second, civil society may advocate for but may not represent individuals. The former suggests a hierarchical relationship between civil society as advocate and the objects of its activity. Such advocacy may be institutionally necessary for the maximization of the welfare of the civil society institution in the worlds in which they operate, but it tends to obliterate the individual, except as data input for policy. ${ }^{71}$ The latter suggests a deeper and more horizontal fiduciary relationship, one that might mimic the mechanics of the direct relationship between electorate and government in states. Individuals are represented by civil society only as members. But civil society advocates for substantially broader groups of individuals, whom they also "represent." Yet the objects of advocacy-representation may not even know of this representation when advanced in venues like the Forum, or even of that advocacy relationship itself. Representation through advocacy can hardly substitute for conventional representation in the political sense. The weakness of the substitution effect is apparent, especially where

70. Marbury v. Madison, 5 U.S. 137, 175 (1803) (holding that the establishment of the federal government of the United States is by direct act of the people, rather indirectly by act of the several states assembled in Congress).

71. Gabriel Moreno González noted:

"Un hombre, una célula; un conjunto de células, una ciudad". Con este título sobrevolando las mentes de los asistentes, dictó en octubre de 1929 Le Corbusier una conferencia en Buenos Aires sobre las nuevas tendencias del urbanismo. Para uno de los mayores teóricos de la arquitectura contemporánea, un hombre no es más que un conjunto de células que, agrupadas a su vez bajo las distintas formas de «hombres», forman las ciudades. Gabriel Moreno González, Los Demonios del Hombre Autónomo y la Hybris Prometeica, A PARTE REI. REVISTA DE FILOSOFÍA 1, 1 (Nov. 2010) (Spain), available at http://serbal.pntic. mec.es/AParteRei/moreno72.pdf. 
civil society seeks to speak for the groups on whose behalf it advocates in governmental or quasigovernmental contexts. ${ }^{72}$ When advocacy is viewed as the functional equivalent of representation, the representational relationship resembles the relationship between parent and child more than that between elected official and voter. Dependency or service is hardly a legitimate basis for representation.

Third, enterprises, of course, are obligated to represent their shareholders over other stakeholders. Individuals, like components and raw materials, are viewed as factors of production, and corporate interest must be directed to the higher project of maximizing the utility of these factors in the production of wealth for shareholders. Enterprises serve themselves, even when constructing self-constituting governance. ${ }^{73}$ Enterprises, then, suffer the same problem of representational legitimacy as civil society actors with respect to the objects of their advocacy: in both cases, relationships cannot be transmuted into representation on the strength of the relationship alone.

The global mass of individuals, then, may not be represented adequately by any of the conventional representational actors who are commonly supposed to serve in the aggregate as representatives of, and who stand in place of, the mass of individuals, the global population, in international fora. ${ }^{74}$ The mass that is constituted of the mass-global individuals situated beyond the state-must represent itself. Yet orthodox approaches leave few possibilities for this. Conventional approaches would revolve around some form of global government, one with a direct connection between individual and the global apparatus of government. ${ }^{75}$ And, indeed, these might well solve the problem of

72. Cf. Larry Catá Backer, Neo Colonialism in Civil Society Clothing or the Rise of Human Dignity as the First Supra National Principle of International Law?, LAW AT THE END OF THE DAY (May 13, 2008, 2:39:00 PM), http://cbackerblog.blogspot.com/2008/05/ neo-colonialism-in-civil-society.html.

73. Cf. JH Dalhuisen, Legal Orders and Their Manifestation: The Operation of the International Commercial and Financial Legal Order and Its Lex Mercatoria, 24 BERKELEY J. INT'L L. 129, 135 (2006) (noting that the international business community has been less likely to opine on the laws by which it is governed and that it lives in the expectation that applicable law will protect it).

74. Cf. Bardo Fassbender, 'We the Peoples of the United Nations' Constituent Power and Constitutional Form in International Law, in THE PaRAdox of Constitutionalism: CONSTITUENT POWER AND CONSTITUTIONAL ForM 269 (Martin Loughlin \& Neil Walker eds., 2008) (examining the general question of the relationship between power and constitutional form in the context of the international community).

75. See, e.g., Martin Shaw, Theory of the Global State: Globalitiy as an UNFINISHED REVOLUTION (2000) (arguing that globality is the growing sense of worldwide human commonality as a practical social force, arising from political structure). 
representation of the mass of "global" individuals in supranational forums.

What that leaves, then, in lieu of representation of the live bodies of individuals, is abstraction and reconstitution along the lines that produce states, enterprises, and civil society organizations, but with a twist. It follows that data becomes the individual in the halls of the transnational governance. ${ }^{76}$ Facticity and representation are derived from the assemblage of numbers representing the incarnation of individuals as a body, ${ }^{77}$ and only as a body does the individual acquire significance within the discourse of law, especially the law and normative structures of human rights in business. ${ }^{78}$ As Nikolas Rose recently noted, mass democracy and other mass engagements operate on populations that have been calculated. ${ }^{79}$ As in democratic politics, the politics of business and human rights has given rise not only to actors who calculate and to regimes of the expertise of number; it has also produced a governance discourse grounded in data and its cultivation in which the individual is only known by her relation to a set of legitimating statistics. ${ }^{80}$

Democratic power is calculated power, and numbers are
intrinsic to the forms of justification that give legitimacy
to political power in democracies. Democratic power is
calculating power, and numbers are integral to the
technologies that seek to give effect to democracy as a

76. See generally Bruce Curtis, The Politics of Population: State Formation, STATISTICS, AND THE CENSUS OF CANADA, 1840-1875 (2002) (discussing the developing knowledge capacities of the state in Victorian Canada).

77. Cf. Scott M. Campbell, The Early HeidegGer's Philosophy of Life: Facticity, BEING, AND LANGUAGE (2012) (analyzing the concept of facticity and its relation to life and language). See generally Martin Heidegger, ONTOLOGY-THE HERMENEUTICS OF FACTICITY (John van Buren trans., Indiana Univ. Press 1999) (1988) (reviewing critical appropriations of the hermeneutic tradition in order to formulate the question of being on the basis of facticity in the everyday world).

78. Here the allusion is to being in the world. Cf. Evelyn S. Ruppert, II Is; Therefore I am: The Census as Practice of Double Identification, 13 SOC. RES. ONLINE I 1.1 (July 31, 2008), http://www.socresonline.org.uk/13/4/6.html ("Numbers occupy a privileged status in modern political culture. Discourse and debates in the media, academia and government on everything from the economy and health to crime and immigration are often driven and framed in reference to numbers.").

79. Nikolas Rose, Governing by Number: Figuring Out Democracy, 16 ACCT. ORGs. \& SoC'Y 673, 675 (1991) ('[T]here is a constitutive interrelationship between quantification and democratic government.").

80. See generally Larry Catá Backer, Global Panopticism: States, Corporations, and the Governance Effects of Monitoring Regimes, 15 IND. J. GLOBAL LEGAL STUD. 101 (2008) (discussing surveillance as a new form of lawmaking through which old boundaries between the public and private, national and transnational, are not relevant). 
particular set of mechanisms of rule. Democratic power requires citizens who calculate about power, and numeracy and a numericized space of public discourse are essential for making up self-controlling democratic citizens. ${ }^{81}$

So it is as well in the context of the individual within systems of business and human rights. The individual counts for very little. The counted individual, however, serves a vastly important purpose, as both the constructed object around which human rights is built, and as the "type" for which remedy is available. 82

In this context, the mass individual, constituted as data, has no vessel through which it makes its presence felt, through which it may engage as representative of itself and its "demos." But the solution may well be embedded in the limits of analogy. Where an aggregating structure is absent, and representation required, it may then be the duty of the institution within which such representation is required to "speak" for the aggregated mass individual.

This requires devoting substantial efforts to the hard task of representing them as they are, and doing so as to make these individuals most accessible-through the data necessary to understand the conditions, values, desires, and objectives of the groups to which states, business, and civil society are obliged in the matter of human rights. But data is precisely what is notable by its absence from the discussions and politics of the Forum's estates general. John Ruggie noted wisely that one can (to borrow a phrase from the Chinese) only come to truth from facts. ${ }^{83}$ Yet it is those facts, that data, that now no longer appears to have a significant enough space in these fora. No place appears where the aggregated individual can shift position from object-fractured into data subsets and constituted to provide a picture of an object on which to act-to actor, either representing herself or represented by an architecture of aggregating representation directly

81. Rose, supra note 79.

82. Cf. Evelyn Ruppert, Population Objects: Interpassive Subjects, 45 Soc. 218, 219 (2011) (noting that metrics enact populations by assembling different categories and measurements of subjects-biographical, biometric, and transactional-to identify and measure).

83. Comm'n on Hum. Rts., Promotion and Protection of Human Rights: Interim Report of the Special Representative of the Secretary-General on the Issue of Human Rights and Transnational Corporations and Other Business Enterprises, I 7, U.N. Doc. E/CN.4/2006/97 (Feb. 22, 2006), available at http://www.ohchr.org/EN/Issues/

TransnationalCorporations/Pages/Reports.aspx (locate document under list) ("[T]he mandate is intended to be primarily evidence based, and also to provide conceptual clarification where called for or otherwise required."). 
connected to the global mass of individuals. Until that obstacle is overcome, the issue of representation remains problematic at the international level, the individual as an autonomous actor remains unrepresented, and the legitimacy of those efforts around this mass individual at the international level remains in question.

\section{ABSTRACTED TERRAINS}

When one moves from the fractured territories of representation at the international level back to the state as recipient and architect of international norms, one enters a landscape of unbroken territory composed of abstracted terrains of law and governance. That movement also brings forward the problem of representation and the legitimacy of acts, but in this context, the difficulty centers on the object of representation. If the development of an international architecture, or architectures, of human rights norms consolidates the "global" individual as an object of such norm-making, the same trend simultaneously produces abstracted terrains within the state of multiple masters, which political representatives may not be able to serve simultaneously.

The development of an international architecture for business and human rights has changed both the source of a representative's fidelity and the identity of those she represents. As enterprises become territories of law systems, and as the expression of popular will becomes subsumed in law and norm to international governance regimes, individuals become subsumed within communities that increasingly serve as a vehicle through which individual rights and interventions may be realized in the international sphere. ${ }^{84}$ Just as the individual poses a challenge for representational legitimacy at international-level norm-making sites, so the increasing authority of international norms poses a challenge for representational legitimacy within the state, now transformed from an apparatus for the realization of popular sovereignty into a fractured terrain of balkanized regimes of general will. Here again, individuals are abstracted into objects. But in contrast to the representational issues in the international sphere, at the national level that abstracting process is undertaken in the service of a transformation of representational obligation from the polity to higherorder entities, whose interests may trump those of the polity itself. ${ }^{85}$

84. The conceptual origins are well forecasted in CARR, supra note 20.

85. Cf. Thomas Risse \& Kathryn Sikkink, The Socialization of International Human Rights Norms Into Domestic Practices: An Introduction, in THE PowER OF HUMAN RIGHTS: InTERnational NoRms AND DOMEstic Change (Thomas Risse et al. eds., 1999) 
The UNGP also point to the ways in which that focus on the state as the central element of a governance framework for business and human rights has also produced perverse effects. ${ }^{86}$ In particular, the greater focus on the state as a center of the global project of managing economic behavior with respect to its human rights impacts has effectively decentered the state and produced a profound challenge to its integrity and coherence as a unit of governance through law. ${ }^{87}$ The more that the global structures of law focus on the state, the more profoundly the state disintegrates as a unitary site for law grounded in popular representation reflecting popular preferences and subject to popular accountability.

As part of this institutional focus on the state in the UNGP, the Working Group has devoted substantial resources to its toolkit of National Action Plans (NAPs). ${ }^{88}$ The Working Group recommended that governments follow four underlying principles in developing their National Action Plans: (1) focus on adverse human rights impacts, (2) focus on methods to address these adverse impacts, (3) identify a regulatory mix of mandatory and voluntary and national and international measures, and (4) take into account differential impacts on vulnerable groups. ${ }^{89}$

The NAPs suggest the scope of the challenge to conventional democratic representation within states represented by the UNGP NAP project. The first touches on the way that the UNGP, through the NAPs, evince a turn toward the acceptance of a hierarchy of law in which national law is always subordinate to international law and perhaps international norms (in the societal sphere at least). The second touches on the efforts to legitimate and expand the extraterritorial power of the state. Both tendencies spring directly from the Guiding Principles themselves. ${ }^{90}$

(describing the socialization process by which international norms are internalized and implemented domestically).

86. See generally Larry Catá Backer, The 2nd U.N. Forum on Busness [sic] and Human Rights Live Streaming and Thoughts on Trends in Managing Business Behaviors, LAW AT THE END OF THE DAY (Dec. 03, 2013, 5:59 AM), http://lcbackerblog.blogspot.com/2013/12/ the-2nd-un-forum-on-busness-and-human.html (offering thoughts and comments on the 2013 U.N. Forum on Business and Human Rights held in Geneva, Switzerland).

87. Cf. Sol Picciotto, Networks in International Economic Integration: Fragmented States and the Dilemmas of Neo-Liberalism, 17 NW. J. INT'L L. \& BUS. 1014, 1018 (1997) (arguing that a growing fragmentation of the classical liberal internationalist system has shifted states from government to governance).

88. See U.N. Working Group on Business and Human Rights, Guidance on National Action Plans on Business and Human Rights (Dec. 2014), http://www.ohchr.org/ Documents/Issues/Business/UNWG_\%20NAPGuidance.pdf.

89. Id. at iii.

90. See Guiding Principles on Business, supra note 7, at 3-12. 
Ironically, this focus, contemplated under the UNGP,91 may transform the state from a unitary site for the application of law constrained by principles of popular representational democracy, 92 into an abstracted terrain in which law is partitioned within the state among distinct categories of legal objects, each distinctly represented through state officials ostensibly obliged to their polities. The effect is to acknowledge both the primacy of international obligation, the law of contract applied to international agreements, and the possibility that such contracts can abstract and divide the terrains of national territory, placing portions of these abstracted terrains beyond the reach of the polity.

Additionally, the promotion of extraterritoriality (now quite fashionable among certain influential sectors of internationalist elites), even under the guise of furthering the international soft-law agenda of devices like the UNGP, ${ }^{93}$ also contributes to the abstraction of nationalterritorial cohesion and decenters the representational heart of national governance. ${ }^{94}$ Yet the approach will further the move toward institutionalizing the hierarchy of states, ${ }^{95}$ and may displace national law with the determinations of foreign states within abstracted portions of national activity. In this way, extraterritoriality effectively shortcircuits the foundational representational relationship between the governed and their elected officials, interposing the domestic policy preferences of the people of a different polity, ${ }^{96}$ or the preferences of a

91. The UNGP are concerned with policy coherence, but in that context note the power of international agreements to subvert expressions of the national will through legislation. See Guiding Principles on Business, supra note 7, at 11 ("States should maintain adequate domestic policy space to meet their human rights obligations when pursuing businessrelated policy objectives with other States or business enterprises, for instance through investment treaties or contracts."); $i d$. at 8 ("States should exercise adequate oversight in order to meet their international human rights obligations when they contract with, or legislate for, business enterprises to provide services that may impact upon the enjoyment of human rights.").

92. See, e.g., Joshua CoHen, Deliberation and Democratic Legitimacy, in THE GoOD Polity: Normative ANalysis of THE State, 18-19 (Alan P. Hamlin \& Philip Pettit eds., 1989); Bernard Manin et al., On Legitimacy and Political Deliberation, 15 POL. THEORY 338, 358-62 (1987).

93. Guiding Principles on Business, supra note 7.

94. The Commentary to UNGP Principle 2 suggests a policy basis for extraterritoriality. See Guiding Principles on Business, supra note 7, at 4 ("The reasons include ensuring predictability for business enterprises by providing coherent and consistent messages, and preserving the State's own reputation.").

95. See Larry Catá Backer, Economic Globalization Ascendant and The Crisis of the State: Four Perspectives on the Emerging Ideology of the State in the New Global Order, 17 BERKELEY LA RAZA L.J. 141, 156 (2006).

96. See Turan KAYAOĞLU, LEgAL IMPERLALISM: SOVEREIGNTY AND EXTRATERRITORIALITY IN JAPAN, THE OTTOMAN EMPIRE, AND CHINA 191-92 (reprt. 2011). 
foreign polity for a particular reading of international law. ${ }^{97}$ Where such extraterritorial application is made effective only outside the jurisdiction of the state projecting its laws outward, then the disconnect between law and polity is complete. ${ }^{98}$

The extraterritorial application of domestic law or of an international normative architecture situated above domestic legal regimes is one manifestation of a general pattern of abstracting national terrains in the broader context of which business operates in and across the national territories of states. By its division of national territory into functionally differentiated regulatory terrains, extraterritoriality challenges the representational connection between polity and national representative with delegitimating effect.99 One can understand these sites of regulation within a national territory as consisting of, in addition to domestic law, enterprise self-regulation, regulation through nongovernmental organizations, extraterritorial regulation, bilateral regulation, and multilateral regulation. Each is briefly considered in turn.

Enterprise self-regulation follows from the increasing autonomy of MNEs from the possibility of control through the application of the domestic law of any one state to all of its operations and activities. ${ }^{100}$ Within the global operations of enterprises which operate across borders in integrated supply chains, the possibility of creating substantial governance operations within the enterprise and among its various units produces the stability of regulatory coherence that is the hallmark of legal systems. ${ }^{101}$ These produce a new form of territorial integrity that functions much like (and across) the national territories of conventional states, ${ }^{102}$ but within which states and their domestic legal orders form only variable components. ${ }^{103}$ It is to the harmonization of

97. See Marko Milanovic, Extraterritorial Application of Human Rights TREATIES: LAW, PRINCIPLES, AND POLICY 151 (2011).

98. See generally Sara L. Seck, LAW AT THE END OF THE DAY, Emerging Market Multinational Home States, Extractive Industries, and the Inside/Outside Problem (July 2, 2015, 4:53 PM), http://cbackerblog.blogspot.com/2015/07/sara-seck-on-emerging-market. html.

99. Cf. David Plotke, Representation is Democracy, 4 Constellations 19, 32 (1997).

100. See, e.g., Jean-Philippe Robé, Multinational Enterprises: The Constitution of a Pluralistic Legal Order, in Global LaW WiThouT A STATE 45, 48-49 (Gunther Teubner ed., 1997).

101. See, e.g., Backer, supra note 69, at 1752-54; Larry Catá Backer, Multinational Corporations as Objects and Sources of Transnational Regulation, 14 ILSA J. INT'L \& COMP. L. 499, 504 (2008).

102. See generally Boaventura de Sousa Santos, Toward a New Legal Common SENSE: LAW, GLOBALIZATION, AND EMANCIPATION 208-15, 257-301 (2d ed. 2002).

103. See Gunther Teubner, Global Bukowina: Legal Pluralism in the World Society, in Global LAW WithouT A STATE 3, 4 (Gunther Teubner ed., 1997). 
these enterprise-specific governance territories that the second pillar of the UNGP was directed.104 Every enterprise carries its own domestic legal order on its back and within its supply chain.

Nongovernmental organizations (NGOs) also project regulatory power within states through the exercise of an authority to regulate the standards for production processes. 105 That regulation takes two forms. The first includes the establishment of normative standards for production, including self-regulatory standards, ${ }^{106}$ environmental standards, ${ }^{107}$ and corporate social responsibility standards. ${ }^{108}$ The second includes NGOs that audit and certify transactions, ${ }^{109}$ or operations, ${ }^{110}$ in accordance with substantive standards of conduct. On occasion, civil society and transnational economic enterprises negotiate hybrid certification regimes that are imposed on transnational economic activities-the Kimberley Process Certification Scheme being among the most well known. ${ }^{111}$ These suggest the power of private actors as representative organs of distinct transnational communities negotiating governance structures with national effect. Yet that very process also highlights the absence of much national will to embed such structures within the state apparatus. ${ }^{112}$

Extraterritorial legislation can sometimes transform enterprises into national territory which is projected into all states in which the enterprise operates. ${ }^{113}$ It commonly applies to specific regulatory

104. See Larry Catá Backer, On the Evolution of the United Nations' "Protect-RespectRemedy" Project: The State, the Corporation and Human Rights in a Global Governance Context, 9 SANTA Clara J. INT'L L. 37, 74 (2011).

105. See, e.g., Jennifer Clapp, The Privatization of Global Environmental Governance: ISO 14000 and the Developing World, in THE BUSINESS OF GLOBAL ENVIRONMENTAL GOVERNANCE 223 (David L. Levy \& Peter J. Newell, eds., 2005).

106. See generally Structure and Governance, Int'l Org. for Standardization [ISO], http://www.iso.org/iso/home/about/about_governance.htm (last visited Sept. 10, 2015).

107. See generally INT'L ORG. FOR STANDARDIZATION [ISO], Environmental Management Systems - Requirements With Guidance For Use, ISO14001 (2d ed., Nov. 15, 2004).

108. See generally INT'L ORG. FOR STANDARDIZATION [ISO], Guidance on Social Responsibility, ISO26000 (Nov. 1, 2010).

109. See generally Who We Are, FAIRTRADEUSA.ORG, http://www.fairtradeusa.org/aboutfair-trade-usa/who-we-are.

110. See generally FAIR LABOR ASs'N, About Us, FAIRLABOR.ORG, http://www.fairlabor. org/about-us-0.

111. See generally Virginia Haufler, The Kimberley Process Certification Scheme: An Innovation in Global Governance and Conflict Prevention, 89 J. BUS. ETHICS (SUPP. 4: Peace Through Commerce: A Multisectoral ApProach) 403 (2009).

112. See id. at 404.

113. See, e.g., In re Copper Antitrust Litig., 117 F. Supp. 2d 875, 887 (W.D. Wis. 2000) ("Congress extends domestic jurisdiction to extraterritorial conduct only when the plaintiffs have been injured by the effects on the domestic market. This is consistent with the main purpose of the Foreign Trade Antitrust Improvements Act, which was to protect 
areas, ${ }^{114}$ but may also subject a foreign enterprise to jurisdiction relating to the activities of a related member. ${ }^{115}$ Thus, an enterprise may be subject to the law of the state in which it operates with respect to some aspects of operation, but subject to the laws of another state with respect to other aspects. The American Foreign Corrupt Practices Act provides a good example of this sort of multijurisdictional effect. ${ }^{116}$

Bilateral and multilateral regulation provide additional bases for distinguishing the legal treatment of people operating within a national territory on the basis of the coverage of each. The principal effect of bilateral treaties is to substitute international for national law covering a distinct subset of national actors, thus distinguishing their treatment from the rest of the polity. Bilateral investment treaties (BITs) permit variations in the construction of domestic legal orders within a domestic legal order-internationalizing part while leaving other parts untouched.117 While most are similar, there are differences among them, creating the possibilities for distinct treatment in some respects among the investment activities falling within their scope. While many BITs provide for "national treatment," some provide for preferential treatment of incoming investment, or "most-favored-nation" treatment. ${ }^{118}$ The effect, of course, is that investments covered under

American exporters from liability under the Sherman Act where the exporters were operating abroad.").

114. For an example of competition law, see, for example, M. Sornarajah, The Extraterritorial Enforcement of U.S. Antitrust Laws: Conflict and Compromise, 31 IN'T'L \& COMP. L.Q. 127 (1982) (as applied to an instance involving Commonwealth countries).

115. See, e.g., 28 U.S.C. $§ 1350$ (1948); but see Kiobel v. Royal Dutch Petroleum Co., 133 S.Ct. 1659 (2013).

116. See generally Foreign Corrupt Practices Act (FCPA), 15 U.S.C. $\S 78$ dd-1 (1977).

117. See generally Tom Ginsburg, International Substitutes for Domestic Institutions: Bilateral Investment Treaties and Governance, 25 INT'L REV. L. \& ECON. 107 (2005) (demonstrating how the substitution effect of BITs may reduce governance quality of domestic legal orders of developing states).

118. A number of states have produced model BITs from out of which negotiations usually proceed. See, e.g., Agreement Between Canada and ......... For the Promotion and Protection of Investments, ITALAW.COM (2004), http://italaw.com/documents/Canadian2004FIPA-model-en.pdf; Agreement for the Promotion and Protection of Investments Between the Republic of Colombia and ___, ITALAW.COM (2004), http://italaw.com/documents/ inv_model_bit_colombia.pdf; Draft Agreement Between the Government of the Republic of France and the Government of the Republic of (...) on the Reciprocal Promotion and Protection of Investments, ITALAW.COM (2006), http://italaw.com/documents/ModelTreaty France2006.pdf; Treaty Between the Federal Republic of Germany and . . . . . . . . . Concerning the Encouragement and Reciprocal Protection on Investments, ITALAW.COM (2008), http://www.italaw.com/sites/default/files/archive/ita 1025.pdf; Agreement Between the Government of the Republic of India and the Government of the Republic of (...) for the Promotion and Protection of Investments, ITALAW.COM (2003), http://www.italaw.com/sites/ 
the treaty in the latter case will be subject to some rules distinct from those available to local investments, including remedial rights against the host state. Ironically, in representing the interests of investors, such treaties create an environment in which states may be constrained in the protection of the human rights of their own citizens within their own territory.119 International representation of transnational constituencies, then, may envelop and overwhelm the traditional politically sourced representational element in the constitution of states, where, in the hierarchies of political orders, states cease to occupy the apex of power.

The challenges of the new representational architecture of elected state officials was exposed quite clearly in the wake of the collapse of the Rana Plaza factory building in Bangladesh in $2013 .{ }^{120}$ Immediately after the collapse, the state moved to action, arresting the building owner, the factory owners, and officials who might have violated law in the context of building approvals and inspections. But reform and response to the collapse was another matter. The scope and direction of response were, to a large extent, directed by the MNEs with stakes in Bangladeshi production chains, sometimes in coordination with international organizations, principally the International Labor Organization (ILO). These enterprises sometimes coordinated their efforts, but sometimes broke up into camps competing for control of reform and for influence with the Bangladeshi state. The two most influential camps were the Accord and the Alliance for Bangladesh Worker Safety. ${ }^{121}$ Both focused on the development and implementation

default/files/archive/ita1026.pdf; Treaty Between the Government of the United States of America and the Government of [Country] Concerning the Encouragement and Reciprocal Protection of Investment, ITALAW.COM (2012), http://www.italaw.com/sites/default/files/ archive/ita1028.pdf.

119. See, e.g., LUKe Eric PETerson \& KeVIn R. Gray, Int'L InSt. For SUSTainable

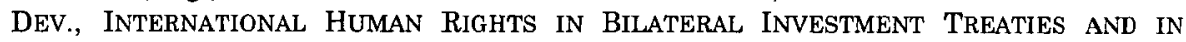
INVESTMENT TREATY ARBITRATION 3 (2003), available at http://www.iisd.org/sites/ default/files/pdf/2003/investment_int_human_rights_bits.pdf ("[T]here is evidence that investment treaty arbitration has been threatened against the South African Government in relation to its policy efforts to promote greater racial diversity in management and ownership positions in the South African economy."); id. at 8-9 ("Some South African BITs do contain exceptions which shelter certain forms of human rights-inspired legislation which might affect foreign investors. However, these provisions are very limited in scope providing an exception only to one of more than a dozen investment treaty provisions.").

120. Discussed in Larry Catá Backer, Are Supply Chains Transnational Legal Orders? What We Can Learn From the Rana Plaza Factory Building Collapse, 1 UC IRVINE J. INT'L, 'TRANSNAT'L, COMP. L. (forthcoming 2016).

121. The Alliance consisted of mostly U.S. enterprises with production chain connections with Bangladesh. It was organized as a partnership among enterprises working together through a loosely based organizational structure. See About The Alliance For Bangladesh Worker Safety, ALLIANCE FOR BANGLADESH WORKER SAFETY, 
of new standards for building inspection and safety. Both also provided financial and technical assistance for factory and building owners affected by their standard-setting-those with connections to global production chains. Both worked with and through the Bangladeshi state, which embraced their approach to inspection and standards. This produced an odd re-embedding of law within a state but grounded in the representational obligation of nonstate actors working to benefit, but not representing, Bangladeshi citizens in the interest of other global orders, ${ }^{122}$ whose legitimacy remains contested. ${ }^{123}$ MNEs also formed the so-called "Arrangement" under which compensatory payment was to be made to claimants, funded by enterprises otherwise beyond the reach of Bangladeshi courts.124 All of these efforts were informed by international business and human rights standards that had been incorporated into the global human rights governance frameworks of these enterprises. Lastly, Bangladesh entered into agreements with the European Union and the United States under which it agreed to substantial changes in its labor law, labor policy, and safety and building inspections to internationalize these areas in ways that suited

http:/www.bangladeshworkersafety.org/who-we-are/about-the-alliance (last visited Nov. 9, 2015) ("The Alliance for Bangladesh Worker Safety was founded by a group of North American apparel companies and retailers and brands who have joined together to develop and launch the Bangladesh Worker Safety Initiative, a binding, five-year undertaking that will be transparent, results-oriented, measurable and verifiable with the intent of improving safety in Bangladeshi ready-made garment (RMG) factories."). The Accord consisted of mostly European and some U.S. enterprises. It was organized as a more open organization, chaired by the ILO, and included space for engagement with local and international civil society and public organizations. See ACCORD ON FIRE AND BUILDING SAFETY IN BANGLADESH, http://bangladeshaccord.org/ (last visited Nov. 9, 2015) ("The Accord is an independent, legally binding agreement between brands and trade unions designed to work towards a safe and healthy Bangladeshi Ready-Made Garment Industry. Our purpose is to enable a working environment in which no worker needs to fear fires, building collapses, or other accidents that could be prevented with reasonable health and safety measures.").

122. This has been viewed as both necessary and positive without any reference to the consequence either for legitimacy or representation. See, e.g., Janelle M. Diller, Pluralism and Privatization in Transnational Labour Regulation: Experience of the International Labour Organization, in RESEARCH HANDBOOK ON TRANSNATIONAL LABOUR LAW 329 (Adelle Blackett \& Anne Trebilcock, eds., 2015).

123. See Dorotheé Baumann-Pauly et al., Closing Governance Gaps in Bangladesh's Garment Industry - The Power and Limitations of Private Governance Schemes 7-17 (Mar. 12, 2015), available at http://ssrn.com/abstract=2577535.

124. See Diller, supra note 122, at 337 ("The Arrangement is governed by a multistakeholder Coordination Committee composed of the signatories (except for one company). . . . The Committee has decided on methods for benefits calculation and distribution, and set up an expert Claims Administration to process victims' claims in as individualized an assessment as possible."). 
both the United States and the European Union. ${ }^{125}$ The most significant changes were to Bangladeshi labor law. The foundation for these changes was international standards now transposed into Bangladeshi law through the intervention of two foreign states representing the interests of workers, including those of Bangladesh. Law and representation now take on a multiple set of quite distinct meanings within the globalized structures of governance-one in which the direct connection between represented and representative becomes more fluid and indirect. With this fluidity and indirectness, the connection between representation and accountability, a touchstone of representation's legitimacy-enhancing function, is as dissipated as the concept of representation in lawmaking itself.

As a consequence, when one looks at the landscape of law in Bangladesh after the collapse of the Rana Plaza factory, one does not see a single domestic legal order coherently and rationally applied to everyone operating within the national territory. Instead, one sees something quite variegated. At the bottom are those firms, individuals, and operations that have no connection to globalized chains of production. For these, the alpha and omega of law and governance is delineated by the traditional boundaries of the state and its operationalization within Bangladeshi democratic structures. But beyond that, governance gets more complex and representation loses its connection to the polity. Competing alliances of multinational enterprises develop inspection standards and train national inspectors, who oversee compliance with these standards but only at factories connected to production chains of alliance participants. The state embraces the inspection standards and proffers its officials for training. Compensation for survivors is overseen by a coalition of entities, itself overseen by an international organization and funded from abroad. Working conditions are set by MNEs with respect to workers in their production chains, but otherwise are set by the state. Finally, however, it is a multilateral group that reaches an agreement for a legislative program and for guidance over the direction of policy to be undertaken within Bangladesh. It is not clear that the Bangladeshi legislature has much room to maneuver here, nor that the Bangladeshi electorate was engaged with this process. Bangladeshi officials, legislative and executive, both sought out and cooperated with these efforts. The consequence was legitimacy for Bangladesh within the international community, but perhaps less so within its territory. The consequence for Bangladesh is a state characterized by a multiplicity reflected in the

125. See Press Release, Eur. Comm'n, Joint Statement by Eur. Comm'n/HRVP \& US Agencies on the Second Anniversary of the Rana Plaza Disaster in Bangl. (Apr. 24, 2015), available at $\mathrm{http}: / /$ europa.eu/rapid/press-release_STATEMENT-15-4849_en.htm. 
divided representation of its officials. This is not the relational structure of a traditional democratic state, even one imperfectly operated. This is something quite new. Here, it is no longer clear how tightly representatives are now connected, or whether they are connected at all, to the individuals who elected them and to whom they might otherwise, and in another era, have been solely accountable.

From the perspective of representation, then, something curious appears to have emerged. One might conceive of this as representational anarchy-the possibility of representation unmoored to either territory or an ordering scheme of representational hierarchy. It is not merely a matter of misalignment-something of a standard and pragmatic approach to the issue, in line with the primacy of economic modeling of relationships through law. ${ }^{126}$ Rather, from the perspective of political legitimacy, polycentricity and misalignment in the representational legitimacy of actors produce what ought to be understood as classical anarchy127 - a system without a centering point, without an ordering authority, but distinguishable from chaos-the absence of systemicity. Yet that absence of centering principle-the state-produces a crisis of legitimacy, and thus an explanation for the reluctance of states and other actors to rely on emerging governance orders projected inward in ways that weaken the political cohesion of receiving governance organs. And yet, within the polycentric anarchy is the new multilayered universe of governance-the effects of which are felt within states though there may be little direct connection with states, and which may represent the interest of communities for which accountability rests wholly without the state. The people of a state, in this construct, are submerged within the internationalized abstracted citizen, and the representation of this globalized abstracted individual is no longer tied to the population of a state or its political systems. Legitimacy and representation are diffused, but does this represent the will of the represented? The internationalized individual whom transnational actors now purport to serve is a construct of data (the object of human rights regimes). Yet a curious transformation occurs in the context of the relationship between transnational actors and the abstracted individuals they serve. As the example from Bangladesh intimates, civil society, international organization, enterprises, and developed states with an obligation to serve all actors within global production chains

126. See, e.g., Kishanthi Parella, Outsourcing Corporate Accountability, 89 WASH. L. REV. 747 (2014).

127. From the Greek "anarkhos," meaning "without head or chief." Entries 7756-7758 of 119553, THE ONLINE LIDDELL-SCOTT-JONES GREEK-ENGLISH LEXICON, THESAURUS LINGUAE GRAECAE, http://stephanus.tlg.uci.edu/1sj/\#eid=7757\&context=lsj\&action=hw. list-click (last visited Nov. 9, 2015). 
increasingly appear to substitute themselves for the polity, for individual citizens, in the operation of representative democracy within developing states. Democratic representation appears to have lost its individual character, as political rights of individuals now appear increasingly exercised through representational institutional actors. ${ }^{128}$ That is a curious transformation indeed!

\section{CONCLUSION}

Representation has served as the foundation of modern theories of democratic legitimacy-at least for states. As states become increasingly decentered, both from law and norm-making, the legitimating foundation of representation has also been challenged. This essay has explored two distinct forms of that challenge at the center of current approaches to the internationalization of human rights regimes governing behaviors of economic activity within and among states. The first touches on the transformation of the representative. The second touches on the transformation of the state. Together these challenges are transforming representation from a simple and direct relationship between electorate and representative, to one complicated by the obligations of the representative to represent not just the electorate but also the mass of supranational entities and norm-systems to which the state now obliges itself. With this transformation, the legitimacy of the underlying institutions within which representational power is exercised, has been weakened or transformed.

But to the extent transformed, it is not clear that legitimacy grounded in representation and accountability survive. Both forms present significant challenges to legitimacy-based conventional principles of representative democracy and popular sovereignty. Those challenges are particularly acute within the international sphere, where an increasing governance power is in search of the legitimacy of democratic structure, which continues to elude it. In that sphere, the issue of representation turns on the disconnect between the universe of representatives and the mass of represented. States, civil society, and enterprises inadequately represent the global mass of individuals who tend to be the object of international normative efforts, especially in the field of business and human rights. It is as acute within states, where an increasing splintering of legal jurisdiction, in part the result of the

128. See, e.g., Larry Catá Backer, From Guiding Principles to Interpretive Organizations: Developing a Framework for Applying the UNGPs to Disputes That Institutionalizes the Advocacy Role of Civil Society (Penn. St. U. Dickinson Sch. L., Legal Stud. Res. Paper No. 40, 2014) (detailing the current threats to a workable transnational order compatible with the realities of contemporary governance). 
partial projections of international law and norms within states, has severed the traditional connection between representative and polity. Representatives may be elected by the people, but they increasingly owe loyalty to others who constrain their ability to serve their polities. Taken together, these trends suggest a period of instability and transformation of the state, the enterprise, and the individual within the context of a dynamic, transforming notion of representational foundations of democratic legitimacy within and beyond states. 